\title{
Contribution of parental social support and self-control to student truancy behavior
}

\author{
Candra Prasiska Rahmat ${ }^{1}$, Herman Nirwana ${ }^{1}$, Netrawati Netrawati ${ }^{1}$ \\ ${ }^{1}$ Universitas Negeri Padang, Indonesia
}

\begin{tabular}{|c|c|}
\hline Article Info & ABSTRACT \\
\hline Article history: & This study aims to analyze the contribution of parental social support and self- \\
\hline Received Sep $10^{\text {th }}, 2020$ & control both individually and collectively on student truancy behavior. This \\
\hline Revised Oct $11^{\text {th }}, 2020$ & population was vocational high school students Muhammadiyah 1 Padang \\
\hline Accepted Nov $01^{\text {th }}, 2020$ & registered in the odd semester of the school year $2020 / 2021$ as many as 447 \\
\hline Keyword: & $\begin{array}{l}\text { purposive sampling technique. The instrument uses a parental social support } \\
\text { scale, self-control scale and the results of student absenteeism recapitulation. }\end{array}$ \\
\hline Parental social support & The research data were analyzed using descriptive correlational statistics and \\
\hline Self-control & multiple regressions. The research findings proved that parental social support \\
\hline Truancy Behavior & $\begin{array}{l}\text { and self-control simultaneously contributed to student truancy behavior as } \\
\text { much as } 44.5 \% \text {. The implication of the results of this study can be used as } \\
\text { input for creating guidance and counseling service programs in preventing and } \\
\text { reducing truancy in students. }\end{array}$ \\
\hline
\end{tabular}

C 2020 The Authors. Published by Redwhitepress.

This is an open access article under the CC BY-NC-SA license (https://creativecommons.org/licenses/by-nc-sa/4.0/

\section{Corresponding Author:}

Candra Prasiska Rahmat, Universitas Negeri Padang

Email: candraprasiskarahmat1905@gmail.com

\section{Introduction}

Truancy is a major problem at this time in the school environment (Tutiona et al., 2016). The act of truancy is put forward as an answer to the boredom often experienced by students in the school curriculum (Marthen, 2018)(Karpika, Ratih, \& Purnami, 2019). This is indeed a phenomenon that clearly tarnishes the educational institutions themselves. Truancy behavior is a juvenile delinquency (Gase, DeFosset, Kuo, \& Perry, 2016). A form of juvenile delinquency in the process of education at school, namely students who rarely attend school without clear reasons or who are often referred to as truant (Attwood \& Croll, 2015). Another opinion also explains that truancy behavior is one of juvenile delinquencies because it is behavior that describes a violation of school rules (Gentle-Genitty, Karikari, Chen, Wilka, \& Kim, 2015; Mazerolle, Antrobus, Bennett, \& Eggins, 2017).This is in accordance with the research results Mogulescu \& segal (Khadijah, Marjohan, \& Bentri, 2016), that truancy is a serious and troubling problem. Where truancy behavior is believed to be one of the predictors of juvenile delinquency.

Truancy is a student's absence from school without the knowledge or permission of the parents (Keppens \& Spruyt, 2017; Maynard et al., 2017). Students who are truant leave home with the excuse of going to school but turn away and engage in activities outside of school (Cox, 2017; Jennings, 2016). Then Suhendra, Neviyarni, \& Ahmad, (2016) explained that truancy is not attending school that exceeds the regulations set by 
the state, including the number of student attendance at school, provisions for dropping out of school, and the number of absences set by the regulations.

Truancy behavior is mostly practiced among students (Kearney \& Albano, 2018; Önder, 2017; Rogers \& Feller, 2018), not even only in Indonesia. Research result Hixson, (2012) It found that in 2010, in Georgia nearly $10 \%$ of public schools had students who were absent for 15 days or more. Further research results (Bennett, Mazerolle, Antrobus, Eggins, \& Piquero, 2018) revealed that truancy is a significant problem in the United States and in other countries around the world. As happened in the city of Padang, West Sumatra, seven vocational high school students was arrested Satpol PP, Monday January 62020 (tagar.id). The students are known to one of the students vocational high school in Padang City. They were secured by the Satpol PP for wandering around during the study hours. The same thing happened in vocational high school Muhammadiyah 1 Padang, based on the recapitulation of student attendance for one semester of the school year 2019/2020, shows that out of 447 students, 127 students were truant. This shows that more than a quarter of the total students are truant during 5 months of teaching and learning process.

Truancy behavior must be addressed immediately because it can affect academics, morals and other behavior that deviates from school rules (Erlina \& Fitri, 2016). Next, (Fauzana \& Firman, 2019; Murdianti \& Nursalim, 2018) explained that students who often practice truancy at school will have an impact on the learning outcomes they will get.

According to Reid (Yulianthi, Komalasari, \& Mamesah, 2012) explained that the reasons for truancy include students disliking school, boring school conditions, students not doing homework, avoiding exams or tests, displeasing teachers, disliking subjects, being forced to wear school attributes, displeasing friends inside class and feel bored at school. Than (Easton, 2015; Suleman, Hussain, \& Ikram Kayani, 2017) explained that the factors causing truancy at school in students can be grouped into three, namely: (1) school factors, (2) personal factors, and (3) family factors.

One of the factors that influence truancy is family. The family factor referred to in this study is the social support of parents for students in school activities. Parental social support is a support, help, comfort, care, appreciation (Ansong, Okumu, Bowen, Walker, \& Eisensmith, 2017; Thompson \& Goodvin, 2016), or assistance that individuals get from other individuals or groups and includes a communication relationship and interdependent situations. This means that parents' concern for children's education can be manifested in the form of social support provided by parents. The social support you get from parents will provide warmth and intimacy in the family social environment (Astarini, Nirwana, \& Ahmad, 2016; Sucipto, 2017; Yun, Cui, \& Blair, 2016).

With regard to truancy, parents 'lack of social support for children makes children feel uncomfortable and oppose their parents' attitudes (Anam, 2017), one of which is related to school, children protest in the form of truancy or not attending school (Khadijah et al., 2016). Jabar, (2020) said that sometimes parents indirectly encourage their children to skip school by being undisciplined towards their children's attendance at school. In line with that research conducted (Asri \& Nurmina, 2019) described that 7 out of 12 students stated that there were parents who restrained their children, were too busy with work so that the children were not noticed and there were also parents who did not care about their children's education and thought truancy was normal.

In addition, the factors that influence student truancy behavior are personal factors. Personal factors that influence student truancy behavior are self-control. Lack of student self-control causes students to be unable to control and direct behavior in a more positive direction (Devianasari, Suarni, \& Aspin, 2018). Masya \& Kamil, (2019) argued that one of the factors of truancy behavior is a lack of self-control, which makes students skip school. Furthermore, Putra, (2015) explained that it turns out that self-control has an important role in juvenile delinquency. In this case juvenile delinquency in the form of truancy behavior.

Research result Olivia, (2017) it was found that there was a relationship between self-control and truancy behavior of class X vocational high school Country 1 Ngasem School year 2016/2017. Than, research result (Putri, Daharnis, \& Zikra, 2017) proves that there is a significant negative relationship between selfcontrol and student truancy behavior. Weak self-control of students can be seen from the results of the study Astari \& Widagda K., (2014), there are $25.06 \%$ students have moderate self control and $15.93 \%$ students have low self control. Then research from Elani (2015), Student self-control is in the low category $39.1 \%$ and very low $13.8 \%$. The opinion above means that self-control tends to influence students' truancy behavior at school. Students who have low self-control tend to have high truancy behavior.

Guidance and counseling as an integral part of educational activities (Handaka \& Maulana, 2017) has an important role in efforts to develop student abilities, which are related to the activities of students' daily 
effective life (Intani \& Ifdil, 2018). Based on the explanation above, the researcher is interested in conducting research on the contribution of parental social support and self-control to student truancy behavior and its implications in guidance and counseling.

\section{Method}

The research was conducted using descriptive correlational quantitative methods. The study population was 447 students of vocational high school Muhammadiyah 1 Padang who were registered in the odd semester of the 2020/2021 school year and 127 research samples. The sample was selected by purposive sampling technique. The instrument used was the parental social support scale with a reliability of 0.918 , a self-control scale with a reliability of 0.805 and the results of student absenteeism recapitulation. The research data were analyzed using descriptive statistics, simple regression and multiple regression.

\section{Results and Discussions}

\section{Truancy Behavior $(\mathrm{Y})$}

The data description of truancy behavior can be seen in table 1 .

Table 1. Distribution of Frequency and Percentage of Truancy Behavior (Y)

\begin{tabular}{|c|c|c|c|}
\hline Score Interval & Category & Frequency & $(\%)$ \\
\hline$\geq 28$ & Very high & 17 & 13,3 \\
\hline $21-27$ & High & 39 & 30,7 \\
\hline $14-20$ & Moderate & 36 & 28,3 \\
\hline $7-13$ & Low & 27 & 21,2 \\
\hline$\leq 6$ & Very low & 8 & 6,2 \\
\hline \multicolumn{2}{|c|}{ Total } & 127 & 100 \\
\hline
\end{tabular}

Based on table 1, it is known that the frequency of the data obtained was dominated by the majority of students who had a high truancy behavior category as many as 39 students, with the total percentage reaching $30.7 \%$. Meanwhile, in the second place, there were 36 students who had truant behavior category, namely with a percentage of $28.3 \%$. Meanwhile, the frequency of students who had the low truancy behavior category was 27 students with a percentage of $21.2 \%$. Furthermore, the frequency of students who had truant behavior category was very high as many as 17 students with a percentage of $13.3 \%$ and the rest was filled by the frequency of students who had very low truancy behavior as many as 8 students with a percentage of $6.2 \%$ of the total research sample.

\section{Parental social support $\left(\mathrm{X}_{1}\right)$}

The data description of truancy behavior can be seen in table 2 .

Table 2. Distribution of Frequency and Percentage of Parents' Social Support (X1)

\begin{tabular}{|c|c|c|c|}
\hline Score Interval & Category & Frequency & $(\%)$ \\
\hline$\geq 143$ & Very high & 19 & 15 \\
\hline $117-142$ & High & 49 & 39 \\
\hline $91-116$ & Moderate & 59 & 46,4 \\
\hline $65-90$ & Low & 0 & 0 \\
\hline$\leq 64$ & Very low & 0 & 0 \\
\hline \multicolumn{2}{|c|}{ Total } & 127 & 100 \\
\hline
\end{tabular}

Based on table 2, it can be seen that in general students get social support from moderate parents, namely the percentage reaching 46.4\%. Meanwhile, the percentage of students who have social support from parents is $39 \%$. Furthermore, the percentage of students who have social support from parents is very high, the percentage is $15 \%$, and there are no students who have low and very low categories of social support from parents.

\section{Self control $\left(\mathrm{X}_{2}\right)$}

The data description of truancy behavior can be seen in table 3. Based on table 3 , it is known that the frequency of the data obtained was dominated by the majority of students who had moderate selfcontrol, namely the percentage reaching $45.66 \%$. While in the second place dominated by students who have a high self-control category with a percentage of $42.51 \%$. 
Table 3. Distribution of Frequency and Percentage of Parents' Social Support (X1)

\begin{tabular}{ccccc}
\hline Score Interval & Category & Frequency & $\mathbf{( \% )}$ \\
\hline $\mathbf{9 2}$ & & Very high & 4 & 3,14 \\
$\mathbf{7 5}-\mathbf{9 1}$ & High & 54 & 42,51 \\
$\mathbf{5 8}-\mathbf{7 4}$ & Moderate & 58 & 45,66 \\
$\mathbf{4 1}-\mathbf{5 7}$ & Low & 11 & 8,66 \\
$\leq \mathbf{4 0}$ & & Very low & 0 & 0 \\
& & & $\mathbf{1 2 7}$ & $\mathbf{1 0 0}$ \\
\hline
\end{tabular}

While the frequency of student data who had low self-control category was 11 students with a percentage of $8.66 \%$. The rest is filled with students with very high self-control categories with a percentage of $3.14 \%$ of the total number of research respondents, and no percentage of students who have very low selfcontrol categories. The findings and results of this study consisted of the variables of parental social support (X1), self-control (X2), and student truancy behavior (Y). The following are the results of the data analysis obtained.

Table 4. Contribution analysis of Parental Social Support (X1), Self Control (X2), and Truancy Behavior (Y)

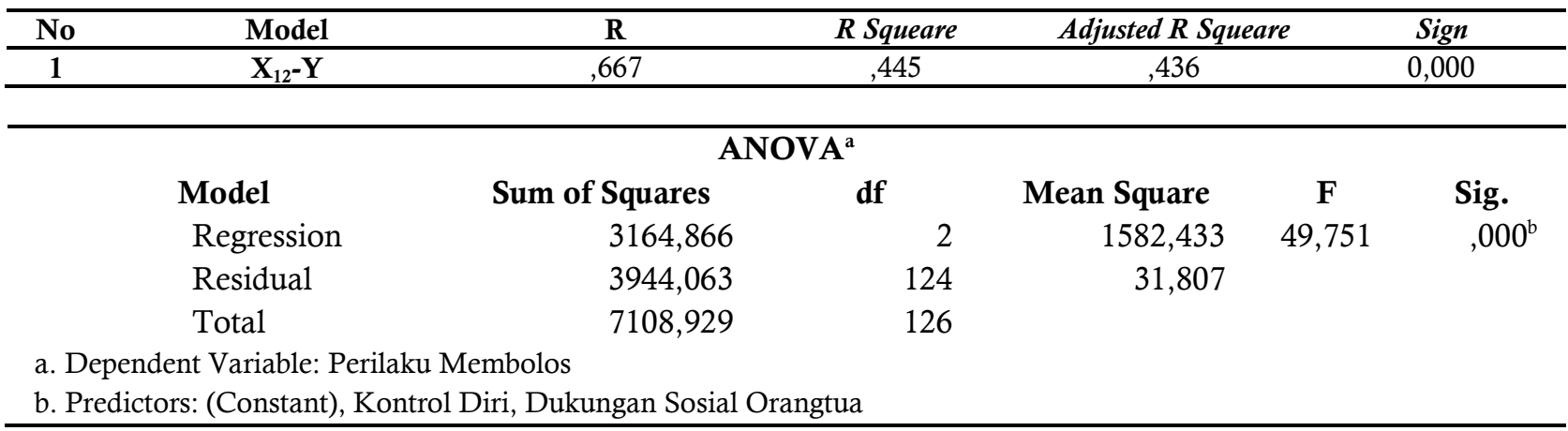

Table 4 in the first model shows that the $\mathrm{R}$ value of parental social support and self-control with truancy behavior is 0.667 , an $\mathrm{R}$ Square value of 0.445 and a significance value of 0.000 , which means that parental social support and self-control jointly contribute to truancy behavior by $44.5 \%$. The remaining $55.5 \%$ is influenced by other variables. So it can be interpreted that truancy behavior is influenced by the level of social support provided by parents to students and self-control possessed by students. If students get high parental social support and have high self-control, the student's truancy behavior will decrease, on the other hand, if students get low parental social support and have low self-control, the student's truancy behavior will increase.

Based on the results of the research data analysis, it was found that social support from parents was still sufficient but still very much needed to be improved, especially in the aspects of instrumental support and emotional support. If the social support provided by parents to children is not fulfilled, the child will tend to oppose the parents' attitude by engaging in truancy. This is in accordance with the opinion (Kraft, 2015; Hardie, 2015), that lack of social support from parents will cause children to tend to oppose their parents by being indifferent and engaging in truancy. The results of the research conducted Sari \& Muis, (2018), shows that the lack of social support from parents in the form of attention from parents so that children feel free to act at will because parents are busy working. So that in the absence of restrictions from parents, students will practice truancy with the assumption that truancy is normal because parents also don't really care about it.

Social support is the support, assistance, comfort, care, appreciation, or assistance that individuals get from other individuals or groups and includes a communication relationship and interdependent situations. (Sarafino \& Smith, 2011; Yulianthi, Komalasari, \& Mamesah, 2012; Handono \& Bashori, 2013; Rokhimah, 2014; Satriana \& Nirwana, 2020). So that children feel comfortable with the presence of parents and helpful relationships when individuals are experiencing problems or difficulties, both in the form of information and real assistance, so as to make individuals feel cared for, valued and loved (Adawiyah, 2013; Saragi, Iswari, \& Mudjiran, 2016).

Various efforts can be made to prevent and reduce truancy in students. One way is to increase parental social support. High parental social support will provide encouragement, enthusiasm, motivation, selfconfidence, and make students want to do learning activities properly and can control their actions so they don't skip truancy. With good social support, it makes children feel comfortable and makes them feel cared for, valued and loved (Hasgimianti, Nirwana, \& Daharnis, 2017). 
In accordance with the opinion Epstein (Maslihah, 2011), parental involvement in children's schools, namely: (1) families have a basic obligation to provide safety and health for their teenagers, (2) schools have a basic obligation to communicate with families about school programs and child development, (3) parents' involvement in schools must be increased, (4) parental involvement in learning activities at home must be increased, (5) parents must be more frequently involved in decision making at school, and (6) collaboration and collaboration with organizations in the community must be increased.

To increase parental social support, guidance and counseling services are needed (Dianto, 2017). Efforts that can be made by the teacher / counselor are to collaborate with parents to monitor the development and activities of students at school. This can be provided during home visits and case conferences. Through home visits, the counselor can establish more effective communication with parents. In this way the counselor can find out how the student is at home, and can discuss the student's problems with both parents so that parents can understand how the child's real condition is and what must be done to help the child so that he can return to school well again (Sari, Yusuf, \& Bentri, 2016; Oktary, Marjohan, \& Syahniar, 2019).

Furthermore, in addition to parental social support, self-control is also a significant predictor of juvenile delinquency in this case, truancy behavior (Benson, 2020; Marcum, Higgins, \& Poff, 2016). Students who have high self-control are able to direct and regulate their behavior, are not easily tempted by changes that occur and can avoid deviant behavior (Thalib, 2017; Ilmi \& Yusri, 2020). In line with that, Ningsih, (2018) also suggests that students can self-regulate and can direct their behavior in a more positive direction if they have high self-control. However, if students have low self-control, it can cause students to violate prevailing social norms such as truancy (Hurley, 2017).

Self-control is very influential in everyday life and it is this self-control that determines the behavior of the individual (Galla \& Wood, 2015; Milyavskaya \& Inzlicht, 2017). students with low self-control will be prone to take deviant actions (Syaibani, Darmayanti, \& Hasanuddin, 2019), while students with high selfcontrol will be able to direct and guide their behavior in a more positive direction, are not easily tempted by the changes that occur and can avoid deviant behavior, especially truancy (Thalib, 2017; Sari, Ifdil, Sano, \& Yendi, 2020). This is also supported by research conducted by Khairunnisa that individuals who have high self-control will avoid a variety of negative behavior, so that individuals are able to withstand the urge or desire to behave negatively that is not in accordance with social norms (Khairunnisa, 2013).

To improve self-control, it is necessary to provide services by counseling teachers by utilizing counseling guidance services, so that students can control themselves not to do deviant behavior and direct behavior in a more positive direction. One of them is group guidance services by utilizing group dynamics. This is in accordance with the opinion Nirwana, (2013), that from some research group guidance is effective enough to develop positive student behavior. Then from several studies, guidance and counseling services that can be used to improve student self-control are as follows: 1) information services, 2) group guidance services, 3) content mastery services, 4) individual counseling services (Putri, Daharnis, \& Marjohan, 2018; Adiyatma, Mudjiran, \& Afdal, 2020).

Group guidance services have three functions, namely: (1) Functioning informative, (2) Functioning development, (3) Functioning preventive and creative. From the implementation of guidance services, the counseling group of counselors can discuss assignment or free topics related to student activities in school and how students control themselves in their behavior, especially truancy (Damayanti \& Ilyas, 2019). Furthermore, to improve students' self-control, individual counseling services can also be used (S. Sari, Yusri, \& Said, 2017; Purwasih, Dharmayana, \& Sulian, 2018). Through individual counseling guidance and counseling teachers can know or obtain psychological facts that can be used as material for mapping students, so that the counseling guidance and counseling teachers can provide optimal services in accordance with the problems faced by these students.

Based on the findings above, it can be interpreted that parental social support and self-control are factors that influence student truancy behavior. Parents' social support is needed by every student. Social support obtained from parents will provide warmth and intimacy in the social environment of the family both physically and physically (Nurmalasari \& Putri, 2015; Astarini, Nirwana \& Ahmad, 2016; Rahmawati, Neviyarni \& Firman, 2016; Husna, 2017). With social support provided by parents, students' self-control will also increase. This is supported by research results (Kholifah \& Rusmawati, 2018), which proves that there is a significant relationship between parental treatment and self-control. Individuals who get good treatment from their parents can lead to high self-control. Self-control is very necessary for individuals, especially students in overcoming their limited abilities and helping to overcome various adverse things that may come from outside themselves, with high self-control so that students can direct their behavior in a more positive direction and stay away from truancy. 
So it can be concluded that parental social support and self-control contribute to student truancy behavior. This means that parental social support and self-control can explain truancy behavior in students. Thus, to prevent and overcome truant behavior, it is very necessary to increase parental social support and selfcontrol. As one of the elements in school.

Guidance and counseling as an integral part of educational activities (Handaka \& Maulana, 2017) has an important role in efforts to develop student abilities, which are related to the activities of students' daily effective life (Intani \& Ifdil, 2018). School guidance and counseling teachers can make efforts to increase parental social support and self-control to prevent and overcome truancy by providing various guidance and counseling services, both individually, classically and in groups (Handaramon, Syahniar, \& Netrawati, 2019; Safitri, Neviyarni, \& Irianto, 2014; Salmi, Hariko, \& Afdal, 2018).

\section{Conclusions}

Based on the findings and results of the study, it can be concluded that parental social support and selfcontrol significantly contributed to student truancy behavior. Based on the results of the study, it is recommended that guidance and counseling teachers make a programmed plan so that it can develop and improve cooperation with parents and school personnel so that it has an impact on preventing and overcoming truancy by providing guidance and counseling services. Then to the principal, as the person in charge of all guidance and counseling service activities in the school as a whole, it is expected to coordinate, supervise and foster all Guidance and Counseling activities programmed and take place at school, and facilitate the implementation of Guidance and Counseling services organized by the Guidance and Counseling, whether the implementation of entering class 1 learning hour per week, as well as the implementation of Guidance and Counseling services outside of learning hours. Furthermore, it is hoped that parents of students will voluntarily cooperate with the school by actively participating in providing social support for children's education, especially in controlling children's behavior both at home and in the school environment. Guidance and counseling teachers cooperate with parents for example through home visits so they can monitor student progress and can be observed regularly. For further researchers it is recommended to study further and more broadly related to the variables of parental social support, self-control and truancy behavior. Among them by increasing the number of samples and the coverage of the research area.

\section{References}

Adawiyah, R. A. R. (2013). Kecerdasan Emosional, Dukungan Sosial dan Kecenderungan Burnout. Persona:Jurnal Psikologi Indonesia, 2(2), 99-107.

Adiyatma, R., Mudjiran, \& Afdal. (2020). The Contribution of Self-Control towards Student Smartphone Addiction. SCHOULID: Indonesia Journal of School Counseling, 5(1), 45-49.

Anam, K. (2017). Hubungan Antara Konformitas dan Dukungan Orangtua Terhadap Prokrastinasi Akademik Siswa SMP Negeri 2 Samarinda. Ejournal Psikologi, 5(1), 1-11.

Ansong, D., Okumu, M., Bowen, G. L., Walker, A. M., \& Eisensmith, S. R. (2017). The role of parent, classmate, and teacher support in student engagement: Evidence from Ghana. International Journal of Educational Development, 54(March), 51-58.

Asri, K. P., \& Nurmina. (2019). Kontribusi pola asuh terhadap perilaku membolos siswa sma pgri di kota padang. Jurnal Riset Psikologi, 1.

Astarini, D., Nirwana, H., \& Ahmad, R. (2016). Hubungan antara Konsep Diri Sosial, Persepsi Siswa tentang Dukungan Sosial Orangtua, dan Teman Sebaya dengan Komunikasi Interpersonal Siswa dan Implikasinya terhadap Pelayanan Bimbingan dan Konseli. Konselor, 5(4), 247.

Astari, L., \& Widagda K., I. (2014). Pengaruh Perbedaan Jenis Kelamin dan Kontrol Diri terhadap Keputusan Pembelian Impulsif Produk Parfum. E-Jurnal Manajemen Universitas Udayana, 3(3), 40-48.

Attwood, G., \& Croll, P. (2015). Truancy and well-being among secondary school pupils in England. Educational Studies, 41(1-2), 14-28.

Bennett, S., Mazerolle, L., Antrobus, E., Eggins, E., \& Piquero, A. R. (2018). Truancy intervention reduces crime: Results from a randomized field trial. Justice Quarterly, 35(2), 309-329.

Benson, B. (2020). The use of the routine activities theory on policing informal settlements in the Global South. South African Geographical Journal, 5(3), 1-18.

Cox, A. L. (2017). Contributing factors of truancy/absenteeism. University of Houston-Clear Lake.

Damayanti, N., \& Ilyas, A. (2019). Self-control profile of students in implementing discipline in school. JPGI (Jurnal Penelitian Guru Indonesia), 3(2), 103-109.

Devianasari, Suarni, W., \& Aspin. (2018). Pengaruh layanan bimbingan kelompok dalam mengembangkan 
kontrol diri siswa SMP Negeri 36 Konawe Selatan. Jurnal Bening, 2(2), 67-78.

Dianto, M. (2017). Profil Dukungan Sosial Orangtua Siswa di SMP Negeri Kecamatan Batang Kapas Pesisir Selatan. Jurnal Counseling Care, 1(1), 42-51.

Easton, L. B. (2015). Professional Development Discussion Guide. Phi Delta Kappan, 96(6), 1-14.

Erlina, N., \& Fitri, L. A. (2016). Penggunaan Layanan Konseling Individu dengan Pendekatan Behavioral untuk Mengurangi Prilaku Membolos Peserta Didik Kelas VIII MTs Miftahul Ulum Merabung Iii Kecamatan Pugung Kabupaten Tanggamus. KONSELI: Jurnal Bimbingan Dan Konseling (E-Journal), 3(1), $19-28$.

Fauzana, A., \& Firman. (2019). The Relationship of Self Determination with Student Learning Outcomes of Skipping at SMAN 5 Pariaman. Jurnal Neo Konseling, 1(2).

Galla, B. M., \& Wood, J. J. (2015). Trait Self-Control Predicts Adolescents' Exposure and Reactivity to Daily Stressful Events. Journal of Personality, 83(1), 69-83.

Gase, L. N., DeFosset, A., Kuo, T., \& Perry, R. (2016). Youths' perspectives on the reasons underlying school truancy and opportunities to improve school attendance. Qualitative Report, 21(2), 299-320.

Gentle-Genitty, C., Karikari, I., Chen, H., Wilka, E., \& Kim, J. (2015). Truancy: a look at definitions in the USA and other territories. Educational Studies, 41(1-2), 62-90.

Handaka, I. B., \& Maulana, C. (2017). Peran Guru Bimbingan dan Konseling dalam Implementasi Gerakan Literasi Nasional. Prosiding Seminar Bimbingan Dan Konseling, 1(1), 227-237.

Handaramon, Y., Syahniar, \& Netrawati. (2019). Self-Adjustment of Truant Students In Vocational High School 5 Padang. 1(3), 1-7.

Hardie, J. H. (2015). The Broken Compass: Parental Involvement with Children's Education. In Contemporary Sociology: A Journal of Reviews (Vol. 44).

Hasgimianti, H., Nirwana, H., \& Daharnis, D. (2017). Perhatian Orangtua dan Motivasi Belajar Siswa Yang Berlatar Belakang Melayu dan Jawa. Insight Jurnal Bimbingan Konseling, 6(2), 130-143.

Hixson, J. T. (2012). The relationship of student family structure and absence type to reading achievement. ProQuest Dissertations and Theses.

Hurley, P. J. (2017). Ego depletion and auditors' busy season. Behavioral Research in Accounting, 29(2), $25-35$.

Ilmi, M., \& Yusri, Y. (2020). Factors Causing Students To Play Truant And Teacher's Efforts To Overcome Them. Jurnal Neo Konseling, 2(1), 1-6.

Intani, C. P., \& Ifdil, I. (2018). Hubungan kontrol diri dengan prestasi belajar siswa. Jurnal EDUCATIO: Jurnal Pendidikan Indonesia, 4(2), 65.

Jabar, M. A. (2020). Qualitative inquiry on parental involvement in children's education: perspectives of parents, children, and teachers in select elementary schools in the Philippines. Asia Pacific Journal of Education, 91(10), 1-15.

Jennings, Z. (2016). Impact of the provision of school lunch on attendance in remote rural Jamaican primary schools. International Journal of Educational Development, 46, 74-81.

Karpika, I. P., Ratih, K., \& Purnami, S. (2019). Penerapan Konseling Behavioral Dengan Media Video Terapi Untuk Mengatasi Perilaku Bolos Siswa Kelas Xi Sma Negeri 1 Abiansemal Tahun Pelajaran 2018 / 2019. Jurnal Pendidikan, 20(2), 315-324.

Kearney, C. A., \& Albano, A. M. (2018). When children refuse school: Therapist guide. Oxford University Press.

Keppens, G., \& Spruyt, B. (2017). Towards a typology of occasional truancy: an operationalisation study of occasional truancy in secondary education in Flanders. Research Papers in Education, 32(1), 121-135.

Khadijah, K., Marjohan, M., \& Bentri, A. (2016). Kontribusi Dukungan Orangtua dan Persepsi Siswa tentang Disiplin Belajar terhadap Perilaku Membolos serta Implikasinya terhadap Layanan Bimbingan dan Konseling. Konselor, 5(3), 172.

Khairunnisa, A. (2013). Hubungan religiusitas dan kontrol diri dengan perilaku seksual pranikah remaja di MAN 1 Samarinda. EJournal Psikologi, 1(2), 220-229.

Kholifah, N., \& Rusmawati, D. (2018). Hubungan Antara Keberfungsian Keluarga Dengan Kontrol Diri Remaja Pada Siswa Sman 2 Semarang. Empati, 7(2), 149-159.

Kraft, I. A. (2015). Normality and Pathology in Childhood: Assessments of Development by Anna Freud. International Journal of Group Psychotherapy, 16(4), 507-509.

Marcum, C. D., Higgins, G. E., \& Poff, B. (2016). Exploratory investigation on theoretical predictors of the electronic leash. Computers in Human Behavior, 61, 213-218.

Marthen, Y. (2018). Pengaruh kontrol diri dan stres sekolah terhadap perilaku membolos siswa smk kesehatan samarinda. Psikoborneo, 6(4), 804-813.

Maslihah, S. (2011). Studi Tentang Hubungan Dukungan Sosial, Penyesuaian Sosial di Lingkungan Sekolah dan Prestasi Akademik Siswa Smpit Assyfa Boarding School Subang Jawa Barat. Jurnal Psikologi Undip, 10(2), 103-114.

Masya, H., \& Kamil, B. (2019). Effectiveness of Self Management in Reducing Truancy Behavior of High 
School Students in Bandar Lampung. KONSELI: Jurnal Bimbingan Dan Konseling (E-Journal), 6(1), 43-48.

Maynard, B. R., Vaughn, M. G., Nelson, E. J., Salas-Wright, C. P., Heyne, D. A., \& Kremer, K. P. (2017). Truancy in the United States: Examining temporal trends and correlates by race, age, and gender. Children and Youth Services Review, 81(August), 188-196.

Mazerolle, L., Antrobus, E., Bennett, S., \& Eggins, E. (2017). Reducing Truancy and Fostering a Willingness to Attend School: Results from a Randomized Trial of a Police-School Partnership Program. Prevention Science, 18(4), 469-480.

Milyavskaya, M., \& Inzlicht, M. (2017). What's So Great About Self-Control? Examining the Importance of Effortful Self-Control and Temptation in Predicting Real-Life Depletion and Goal Attainment. Social Psychological and Personality Science, 8(6), 603-611.

Murdianti, Y. T., \& Nursalim, M. (2018). Studi Tentang Perilaku Membolos Siswa di SMP Negeri 2 Semen Puhsarang Kabupaten Kediri. Jurnal BK UNESA, 9(1), 109-116.

Ningsih, R. (2018). Pengaruh Kontrol Diri terhadap Perilaku Disiplin Remaja. Jurnal Psikoedukasi Dan Konseling, 2(2), 48-52.

Nirwana, H. (2013). Bimbingan Kelompok dan Kesiapan Siswa Dalam Mengikuti Ujian Nasional (UN). 3(1), $17-21$.

Oktary, D., Marjohan, M., \& Syahniar, S. (2019). The Effects of Self-Confidence and Social Support of Parents On Interpersonal Communication of Students. Journal of Educational and Learning Studies, $2(1), 5$.

Olivia, R. F. (2017). Hubungan Antara Kontrol Diri Dengan Perilaku Membolos Siswa Kelas X SMKN 1 Ngasem Kediri Tahun Ajaran 2016/2017. Simki-Pedagogia, 1(3), 1-7.

Önder, E. (2017). Student absenteeism in secondary education, absenteeism-related school practices and recommended policies. Egitim ve Bilim, 42(190), 361-378.

Purwasih, R., Dharmayana, I. W., \& Sulian, I. (2018). Hubungan Kompetensi Kontrol Diri Terhadap Kecenderungan Perilaku Agresif Siswa Smk Bengkulu Utara. Consilia: Jurnal Ilmiah Bimbingan Dan Konseling, 1(1), 52-59.

Putra, A. R. B. (2015). Peran Guru Bimbingan Konseling Mengatasi Kenakalan Remaja di Sekolah. Pedagogik: Jurnal Pendidikan, 10(1), 32-39.

Putri, M. S., Daharnis, D., \& Zikra, Z. (2017). Hubungan Kontrol Diri dengan Perilaku Membolos Siswa. Counsellia: Jurnal Bimbingan Dan Konseling, 6(1), 81-85.

Putri, Y. E., Daharnis, D., \& Marjohan, M. (2018). Self-control of ctudents in using the Internet. Konselor, 7(3), 101-108.

Rogers, T., \& Feller, A. (2018). Reducing student absences at scale by targeting parents' misbeliefs. Nature Human Behaviour, 2(5), 335-342.

Rokhimah, S. (2014). Pengaruh dukungan sosial dan efikasi diri terhadap minat melanjutkan pendidikan ke perguruan tinggi pada SMA Negeri 1 Tenggarong Seberang. Psikoborneo, 2(3), 149-156.

Safitri, N., Neviyarni, \& Irianto, A. (2014). Efektivitas Layanan Bimbingan Kelompok untuk Meningkatkan Motivasi Belajar dan Mengurangi Perilaku Membolos Siswa. Jurnal Konselor, 3(4), 184-200.

Salmi, S., Hariko, R., \& Afdal, A. (2018). Hubungan kontrol diri dengan perilaku bullying siswa. Counsellia: Jurnal Bimbingan Dan Konseling, 8(2), 88.

Sarafino, E. P., \& Smith, T. W. (2011). Health psychology biopsychosocial interaction. United State Of Amerika: John Wlley \& Sons.

Saragi, M. P. D., Iswari, M., \& Mudjiran. (2016). Kontribusi Konsep Diri Dan Dukungan Orangtua. Konselor, $5(1), 1-14$.

Sari, I. P., Ifdil, I., Sano, A., \& Yendi, F. M. (2020). Self-Control of Adolescent in using Smartphone. Jurnal Aplikasi IPTEK Indonesia, 4(2), 101-109.

Sari, S., Yusri, \& Said, A. (2017). Kontrol Diri Siswa dalam Belajar dan Persepsi Siswa terhadap Upaya Guru BK untuk Meningkatkan Kontrol Diri. Jurnal Penelitian Guru Indonesia, 2(1), 32-37.

Sari, U. M., Yusuf, A. M., \& Bentri, A. (2016). Truancy and Implications in Guidance and Counseling. Konselor, 5(3), 151.

Sari, W. P., \& Muis, T. (2018). Studi kasus tentang perilaku membolos siswa si SMA Negeri 1 Plumpang Tuban. Jurnal BK UNESA, 9(1), 23-30.

Satriana, N., \& Nirwana, H. (2020). Contribution of Parents' Support to Adolescent Attitudes About Free Sex Behavior. International Journal of Applied Counseling and Social Sciences, 2(1), 49-54.

Sucipto, S. (2017). Pengaruh Self-Regulated Learning dan Dukungan orangtua Terhadap Hasil Belajar Peserta Didik Pada Mata Pelajaran Ekonomi Program Studi Ips Sma Negeri Di Kota Jombang. Jurnal Ekonomi Pendidikan Dan Kewirausahaan, 2(2), 236.

Suhendra, M., S, N., \& Ahmad, R. (2016). Kontribusi Motivasi Berprestasi terhadap Regulasi Diri Siswa Membolos di Madrasah Aliyah Negeri 2 Payakumbuh serta Implikasinya terhadap Layanan Bimbingan dan Konseling. Konselor, 5(2), 124.

Suleman, Q., Hussain, I., \& Ikram Kayani, A. (2017). Factors Contributing to Truancy Among Secondary School 
Students in Karak District, Pakistan. 8(25), 65-74.

Syaibani, R., Darmayanti, N., \& Hasanuddin. (2019). Hubungan antara dukungan teman sebaya dan kontrol diri dengan kenakalan remaja SMA Swasta Dharmawangsa. PROCEEDING: The Dream of Millenial Generation to Grow, 2(1), 1-10.

Thalib, S. B. (2017). Psikologi pendidikan berbasis analisis empiris aplikatif. Jakarta: Erlangga.

Thompson, R., \& Goodvin, R. (2016). Social Support and Developmental Psychopathology. Developmental Psychopathology, 3(1), 1-49.

Tutiona, Munir, Ratu, Hidayat, S., Suryantoro, H., \& Wiratama, J. (2016). Program Studi Bimbingan dan Konseling, Kampus FKIP Untad Bumi Tadulako Tondo 59. Konseling \& Psikoedukasi, 1(2), 415.

Yulianthi, H., Komalasari, G., \& Mamesah, M. (2012). Faktor penyebab siswa membolos ( Survey pada Siswa Kelas VIII SMP Negeri 232 Jakarta ). INSIGHT: Jurnal Bimbingan Konseling, 1(2), 3-6.

Yun, H. J., Cui, M., \& Blair, B. L. (2016). The Mediating Roles of Adolescent Disclosure and Parental Knowledge in the Association Between Parental Warmth and Delinquency Among Korean Adolescents. Journal of Child and Family Studies, 25(8), 2395-2404. 